Island Studies Journal, Vol. 10, No. 1, 2015, pp. 71-90

\title{
Solving problems, the island way: human resourcefulness in action among the islanders
} of Gozo

\author{
Joseph G. Azzopardi \\ University of Malta, Malta \\ joseph.g.azzopardi@um.edu.mt
}

\begin{abstract}
This paper offers glimpses into how businesspersons, entrepreneurs and small business managers resolve their most pressing problems under conditions characterized by smallness and islandness in order to survive. Applying a nissological approach complemented by an action-oriented grounded method, the researcher explores and inductively analyses the mind-sets of islanders to explicate the basic socio-psychological process that influences how they resourcefully overcome problems associated with mistrust and powerlessness, transforming these into opportunities of trust-building and empowerment. Two concurrent and seemingly contradictory processes emerge from the analysis, suggesting that Gozitans - the residents of the small Mediterranean island of Gozo - apply both overt formal and covert informal processes to solve their problems.
\end{abstract}

Keywords: action research, Gozo, grounded theory, human resourcefulness, island studies, learning and development, nissology

(C) 2015 - Institute of Island Studies, University of Prince Edward Island, Canada

\section{Introduction}

The paper illustrates processes in researching how small island businesspersons, entrepreneurs and small business managers in Gozo engage their most pressing problems to make life viable under limiting conditions of smallness and islandness. Gozo is the second largest island (population: 31,296) in the Maltese archipelago (population: 416,841) (National Statistics Office, 2012). The Maltese islands are situated in the Mediterranean Sea, $100 \mathrm{~km}$ south of Sicily and $290 \mathrm{~km}$ north of Libya (Figure 1). Geographically, Gozo is separated from the main island of Malta by a $5 \mathrm{~km}$ stretch of sea and the only inter-island link today is provided via a frequent ferry service that takes 25 to 30 minutes to cross over. Politically, Gozo is the thirteenth electoral district that falls under the portfolio of the Minister for Gozo who is responsible for the strategic aspects of the socio-economic development of the island, as well as for the day-to-day administrative running of all state departments excluding health and education. Culturally, Gozitans still see themselves as a community with an identity of their own and are perceived likewise by the Maltese.

What guiding principles illuminate Gozo's businesspersons, entrepreneurs and managers in their quest to provide for their own continuous development and business success? A strategy was needed to operationalize a research process that enabled the researcher to proactively learn more about small business managers and entrepreneurs in Gozo and about himself as practitioner-researcher. This entailed addressing the subject-object tension that dominates debate in the social sciences (Remenyi et al., 1998; Smith, 1998; Gummesson, 2000; 2006). By adopting a nissological approach (McCall, 1997; 2002), one 


\section{J. G. Azzopardi}

could inductively indulge in an in-depth research process guided by the belief that "continental thinking misinterprets the economies of small island states ... [and] distorts the true picture of those small island states" (McCall, 1997, p. 3). Instead, islanders and their resourcefulness needed studying "on their own terms" (ibid.).

\section{Figure 1: Map of Malta and Gozo, and their location.}

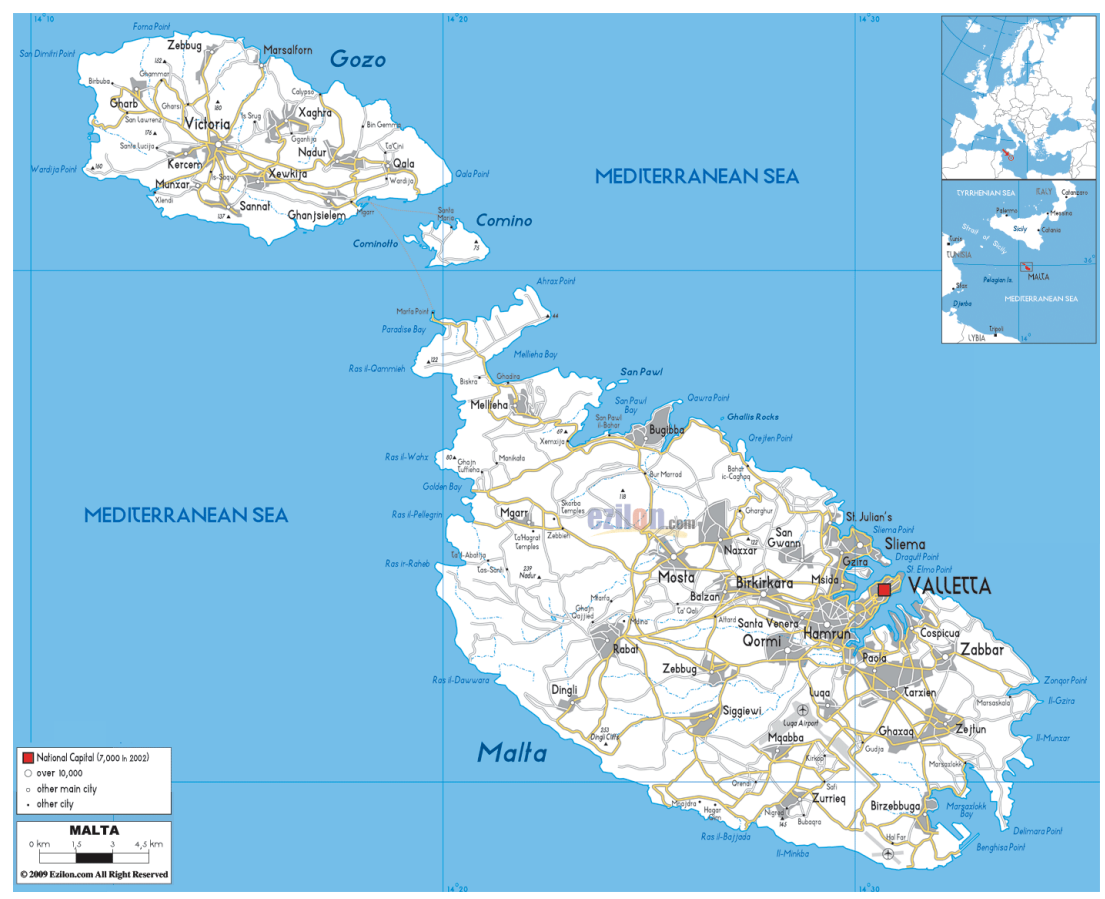

Source: Wikipedia. Retrieved from http://en.wikipedia.org/wiki/Gozo_Channel\#mediaviewer/File:Road-map-of-Malta.gif

McCall argues that 'continental thinking' can misinterpret the economy and distort the true picture of small island worlds if researchers distance themselves from the object of their research and become insensitive to the real concerns of real people in real time. He exposes the limitations of pure 'economistic' approaches to the study of islanders, particularly the economists' fascination with numbers rather than "the behaviour of real human beings" (McCall, 1997, p. 6). He interprets the apparent contradictory results of studies that argue that "islands can be both the site of innovation and conservatism" (ibid., p. 4). He explains the effects of islands" "political position relative to encroaching continental powers" thus,

When Islands control themselves, there is innovation and the elaboration of island high culture in monuments and, probably, other works of art and literature. When, however, Islands fall to continental control, the peripheralized Islanders become conservative, mimic their masters and become exchange-oriented, with island resources in people, materials and ideas flowing to continental cores of power and influence. An Island controlling itself is a powerful engine for creativity; an island controlled by continentals is an island to abandon (McCall, 1997, p. 4). 
To complement this approach, an action research strategy (Stringer, 2014) was adopted; with the researcher observing behaviour and generating data from what was going on in their action scene. To interpret and analyze emerging data, a grounded theory method proposed by Glaser $(1978,1992,1998,2008)$ was used. This blend allowed for the simultaneous tapping into quantitative and qualitative sources of information through a range of data collection methods to generate images, ideas and themes by sampling, analyzing and conceptualizing in an iterative and flexible manner. The goal was to propose a plausible explanation of a real phenomenon in a specific place and time, grounded in credible sources and methods.

Long years of formal education had introduced the researcher to the programmed texts that contained established ideas proposed by successful theorists and practitioners. Past knowns, routines, and procedures soon proved to be insufficient to explain 'how' Gozitans, as islanders, deal with their most pressing problems to survive and keep on developing themselves effectively. New avenues, strategies and tactics were needed to explore new terrains and their hidden attributes.

\section{Let the research question emerge from the data}

To come to terms with the research methods and the respective tools of data generation, the researcher had to iteratively revisit his research question as he moved from one source of information to another, attempting to make more sense out of the data that was being generated. Ethnographers mainly use in-depth interviews and participant observation for indepth study and to generate knowledge about a particular phenomenon or situation. They may remain as detached as possible from that situation, observing it without trying to influence it. In the case of this research, the main objective was to learn more about the substantive field of the researcher's practice while also trying to introduce some changes within it, deliberately trying to alter the situation under study. Unlike the task of the ethnographer, intentionally effecting the situation being researched was central to the original general approach to studying the development of entrepreneurs and managers in Gozo because, while ethnographers participate via observation, the intention here was to participate through action.

Gill and Johnson $(1997 ; 2010)$ explain how ethnography differs from action research. Action researchers enter an organization or community at the request of 'the client', while ethnographers do so after typically having themselves chosen the target group to be studied. In the case of action research, 'the client' therefore remains the owner of the project and the initiative remains with 'the client'. The relationship between the researcher and the client and the psychological contract between them then also become different than what unfolds in ethnography. Because they assume that "they are not in the change business but that their endeavour is to observe how the system works" (Gill \& Johnson, 1997, p. 73), ethnographers enter the community with "the proviso that there will be as little disruption as possible" (ibid.). But the action researcher, assuming that one understands a human system better by trying to change it, deliberately enters the community to generate knowledge and learning through deliberately influencing a change process. Similarly, both action researcher and ethnographer exit the community on differing grounds.

Gill and Johnson (1997, p. 73) propose that, "while the ethnographer's job continues after the fieldwork has finished and data has to be analyzed, normally the [action researcher's] work terminates when he or she leaves the organization". In action research, the researcher 


\section{J. G. Azzopardi}

withdraws from the organization or community when the client has become self-supporting in carrying forward with the change process; while in ethnography, the client remains dependent on the researcher's production of the research results, which may (or may not) be of some value to the organization or the client.

According to Sayer (1992, p. 255), "one possible type of research which might fit the bill in attempting both to investigate and change its object is "action research"." Referring to one particular project, Sayer explains how,

... interviews and questionnaires were not organized so that workers would simply yield up information at the bidding of external researchers who had nothing to offer in return and who would go away and analyze and publish the results in academic seclusion (the usual situation), rather, the research process was kept interactive and open-ended so that workers could pose and discuss questions and hence reconsider their position (Sayer, 1992, p. 255).

This process involves the re-exploration of the original research question, transforming it from one that was pre-determined by the academic researcher to one that is intrinsically valid to the research participants themselves. What are the research participants' main problems? How do entrepreneurs on small islands go about solving them? How do they activate their human resourcefulness to survive and possibly thrive under the real conditions they continuously face in their day-to-day running of their businesses?

As much as the answers to these questions need to emerge and be grounded in real data, so the questions themselves also need to be articulated in the research participants' own words and therefore emerge and be grounded in real data. This led the researcher into the action research mode and therefore into actively contributing through the launching of a management development program involving twenty managers and entrepreneurs, members of the Gozo Business Chamber, interested in doing something about their own development and the development of Gozo. The program was organized in two phases. The first phase was moderated by the researcher with the assistance of two independent external management consultants; the second would have involved all the participants in an action learning development process owned by the participants themselves with the aid of the researcher as facilitator. The first phase constituted the Action Research cycle (Stringer, 2014) through which participants were enabled to 'look' at, 'think' about and 'act' on their current most pressing problems, culminating in a one-day workshop that externalized the participants' latent strengths and weaknesses as individuals and as a business community operating under conditions characterized by smallness and islandness.

The second phase - that is, the action learning management development process however, never materialized. When the research participants were contacted individually by the researcher, they all expressed interest and commitment to the program; however, as a community, they never managed to pull strings together! What was going on? To find an answer to this question, the researcher needed to tap alternative sources of information and, in grounded theory mode, started to explore the phenomenon through a battery of inductive research tools and sources of information that included conference papers, depth-interviews, focus groups, chance conversations, popular wisdom, the researcher's own diary and transcripts of interviews carried out by the external consultants as a follow up to the first phase of the program (see Table 1 below). 
Table 1: Sources of primary qualitative data.

\begin{tabular}{|c|c|c|c|c|}
\hline No. & Method & $\begin{array}{c}\text { No. of } \\
\text { Participants }\end{array}$ & Length/Time & Remarks \\
\hline 1 & In-depth Interviews & 10 & 2 to 3 hours & $\begin{array}{l}\text { Conducted one-to-one in various } \\
\text { locations, except one interview on } \\
\text { telephone, with private and public } \\
\text { sector managers and business } \\
\text { people. Average age of } \\
\text { interviewees: } 45 \text { years }\end{array}$ \\
\hline 2 & $\begin{array}{l}\text { Repeat In-depth } \\
\text { Interviews }\end{array}$ & 5 & $30 \mathrm{~min}$ & Same participants as in No.1 \\
\hline 3 & Focus Group 1 & 8 & $2 \mathrm{hrs} 15 \mathrm{~min}$ & $\begin{array}{l}\text { Planned duration } 1 \mathrm{hr} 30 \mathrm{~min} \\
\text { Participants from public and } \\
\text { private sectors - positions varying } \\
\text { from clerk to supervisor to } \\
\text { manager. } \\
\text { Average age: } 35\end{array}$ \\
\hline 4 & Focus Group 2 & 6 & $2 \mathrm{hrs}$ & $\begin{array}{l}\text { Planned duration } 1 \mathrm{hr} 30 \mathrm{~min} \\
\text { Participants from public and } \\
\text { private sectors - positions varying } \\
\text { from clerk to teacher to manager. } \\
\text { Average age: } 31\end{array}$ \\
\hline 5 & Chance Conversations & Numerous & $\begin{array}{l}10-30 \text { min } \\
\text { (varying) }\end{array}$ & $\begin{array}{l}\text { Continuous process of observation } \\
\text { and informal probing }\end{array}$ \\
\hline 6 & Research Diary & N/A & N/A & $\begin{array}{l}\text { Researcher's own recorded events } \\
\text { and ideas from October } 1998 \\
\text { through September } 2002\end{array}$ \\
\hline 7 & Consultants' Interviews & 20 & $\begin{array}{l}\text { 1hour 30min } \\
\text { (average) }\end{array}$ & $\begin{array}{l}\text { Depth interviews by external } \\
\text { consultants in preparation for the } \\
\text { one-day Workshop }\end{array}$ \\
\hline 8 & Workshop & 17 & One day & $\begin{array}{l}\text { Workshop organized by researcher } \\
\text { and facilitated by two external } \\
\text { consultants }\end{array}$ \\
\hline
\end{tabular}

The conference papers were used to kick-start the coding and analysis process. These originated from three conferences that were topical to the study

- The effects of European Union membership on the island region of Gozo, an event organized by the Gozo Business Chamber on 28th January, 2000, and subsequently published in book form in July, 2000 (Briguglio, 2000); 


\section{J. G. Azzopardi}

- Improving the employability of the workforce in Gozo, an event organized by Bank of Valletta plc on 13th April, 2000, and subsequently published in book form in 2001(Bank of Valletta, 2000);

- Defining the socio-economic character of the island region of Gozo, an event organized by the Gozo Business Chamber in collaboration with the Ministry for Gozo, the Central Office of Statistics, the Gozo Campus of the University of Malta and Bank of Valletta plc, on $23^{\text {rd }}$ March 2001. Its proceedings were not published; the researcher contacted the presenters to request a written copy of their respective presentations.

Presenters at each conference ranged from high-ranking politicians (Prime Minister, Leader of the Opposition, Minister for Gozo, Speaker of the House of Representatives) to business persons, academics, consultants, the Bishop of Gozo, and other observers of the local political, economic and social scene.

Relevant to this methodological discussion is the linguistic factor of the process. The English language was used in the case of the conference papers, the research diary, feedback consultants' interviews, management development workshop and the published and official statistics. But, in the case of the in-depth interviews, focus group discussions, chance conversations and popular wisdom, full benefits were drawn from the natural colloquial contribution that the vernacular Maltese language could give to generating a richer, in vivo understanding of the phenomenon being studied.

Although English is officially the participants' second language, Maltese is still the natural language used conversationally in most informal business and everyday transactions. People in Gozo think in Maltese and their actions are very much influenced by this thinking. During in-depth interviews and focus groups, notes were taken in Maltese and retained in that language when transcribed soon after the event. Translation into English took place upon coding and analysis.

This decision was pivotal to the whole research process. Some Maltese words and expressions did not lend themselves easily to literal translation into English. One recurring expression, widely and consistently used by participants and in daily conversation was $x$ 's $a$ $n \hbar a w d u$ (pronounced: shsan-how-do). This Maltese expression is in the first person plural but intended to be understood as a question in the second person singular: 'What are your plans? What are you up to? How are you doing?' It derives from the Semitic verb: ћawwad (pronounced: how-wat). Aquilina (1987, p. 521) lists nine categories of possible meanings to this verb. Analyzing these categories and the emerging English translations produced no less than nineteen different - and at times even contrasting and divergent - English verbs, depending heavily on the context in which the word is used and on the tone with which the word is pronounced.

The expression $x$ 'sa nћawdu could refer to all of the following: 'Which liquid are we going to stir? Which ingredients do we mix? Whom are we going to upset? How are we to solve this problem? What are your plans? In what intrigue are we indulging? Shall we negotiate this sale? Shall we do business together? Shall we engage in joint work or action?' What's next? Depending on the context in which it is expressed and on the tone used, particularly in a business or work environment, $x$ 'sa nћawdu may infer and communicate contrasting and conflicting meanings and understandings. Inferences range from acts of confusion and acts of design and organization to acts of joint problem solving. 
Aquilina (1987, p. 521) provides examples that elaborate these inferences. Used in one particular context, derivatives of the verb ћawwad may describe a person as untrustworthy: "That person cannot be trusted, and is not consistent." "Don't do any business with that person; s/he is not in the clear/not reliable." At the same time, one can use the verb to manifest signs of trust and confidence when the expression is used to describe business transactions in general, joint action and business partnerships, planning and problem-solving: "I'll see if I can come up with something." "S/he did some business, engaged in joint work or action with someone." "I have a car; do you want me to sell it to you?"

The researcher came to value the richness of $x$ 'sa nћawdu, as it implies meanings that represent the polarities of both the content and the process of the research inquiry: confusion and organization, suspicion and confidence, trust and skepticism. True to the spirit of reflective re-search practice, he came to appreciate how much this term accounts for his own experience: he has found himself lost and confused as he struggled to organize conflicting and contrasting influences on his thinking, encountered difficult times of suspicion about his role and mistrust by his companions and lost confidence and regained trust in his own abilities as

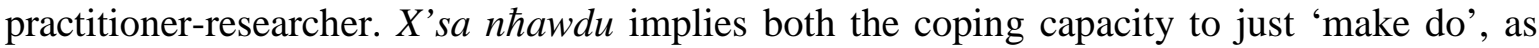
well as the transformative processes to engage the resourcefulness of others in devising solutions to problems in order to make life viable.

Posed as a question, ' $x$ 'sa nhawdu?' provides a metaphor of the central theme of researching entrepreneurs and their development: How do we Gozitan managers and entrepreneurs solve our most pressing problems? How do we use our human resourcefulness to transform problems into opportunities, threats into challenges, mistrust into risk taking, fear and suspicion into security and confidence, powerlessness into empowerment? ' $X$ 'sa $n \hbar a w d u$ ?' embraces the complexities, contradictions, contrasts, opposing values and meanings characterizing this island's action scene and making it worthwhile to account for. Would this research be able to specify the pregnant transformative potential of these islanders' response to ' $X$ 'sa nћawdu?', no doubt lying everywhere and, like the air we breathe, taken for granted? Part of the research process turned out to be the finding of an answer to why something that is so vital and essential can be so commonly used; yet so obvious and so omnipresent that it is easily ignored or simply overlooked. The answer to that question could similarly be another taken-for-granted process that is so deeply ingrained in the islanders' psyche that it becomes the tacit and natural way of dealing with their most pressing problems.

\section{Interweaving programmed knowledge with inquisitive insight}

Although finding an answer to this question involves fresh and innovative endeavours to research beyond extant knowledge, the researcher still felt the need to keep being guided by theories and practices relevant to the evolving subject area of his research interest. Analyzing freshly generated qualitative data in the light of this programmed knowledge stimulated his inquisitive insight to learn more about himself and about the substantive field of his practice. He wanted to interweave the content of his research with the process of its voyage by addressing the relationship between the substantive content of the research, his 'programmed knowledge' with finding an answer to his now central question: 'X'sa nћawdu?'.

Finding answers to this question call for an exploration into the processes people invoke while they try to solve their most pressing problems in order to make life viable in a 


\section{J. G. Azzopardi}

particular setting. Just as in the case of any exploratory voyage, such missions are hardly ever undertaken single-handedly. Collaborators are needed; insiders as well as outsiders, whose ideas, actions, knowledge and insight are essential for the success of the voyage.

Collaborators are those thinkers and practitioners that have influenced this researcher's thinking and practice prior to and during this research voyage, represented by 'programmed texts' and 'virtual and real time companions' and 'published \& official statistics' in Figure 2 below. These embody what Revans $(1998,2011)$ calls Programmed Knowledge $(\mathrm{P})$ in his Action Learning equation: $\mathrm{L}=\mathrm{P}+\mathrm{Q}$, where $\mathrm{L}$ stands for Learning and $\mathrm{Q}$ for Questioning Insight. This programmed knowledge is conventionally referred to as the theoretical foundation of a research study; it is typically reproduced in research papers in a section entitled 'Literature Review'. In the spirit of Revans' Action Learning, the narration of this paper now shifts to the first person singular, the voice of the researcher, himself an islander.

\section{Figure 2: Navigating through the influences of my thinking.}

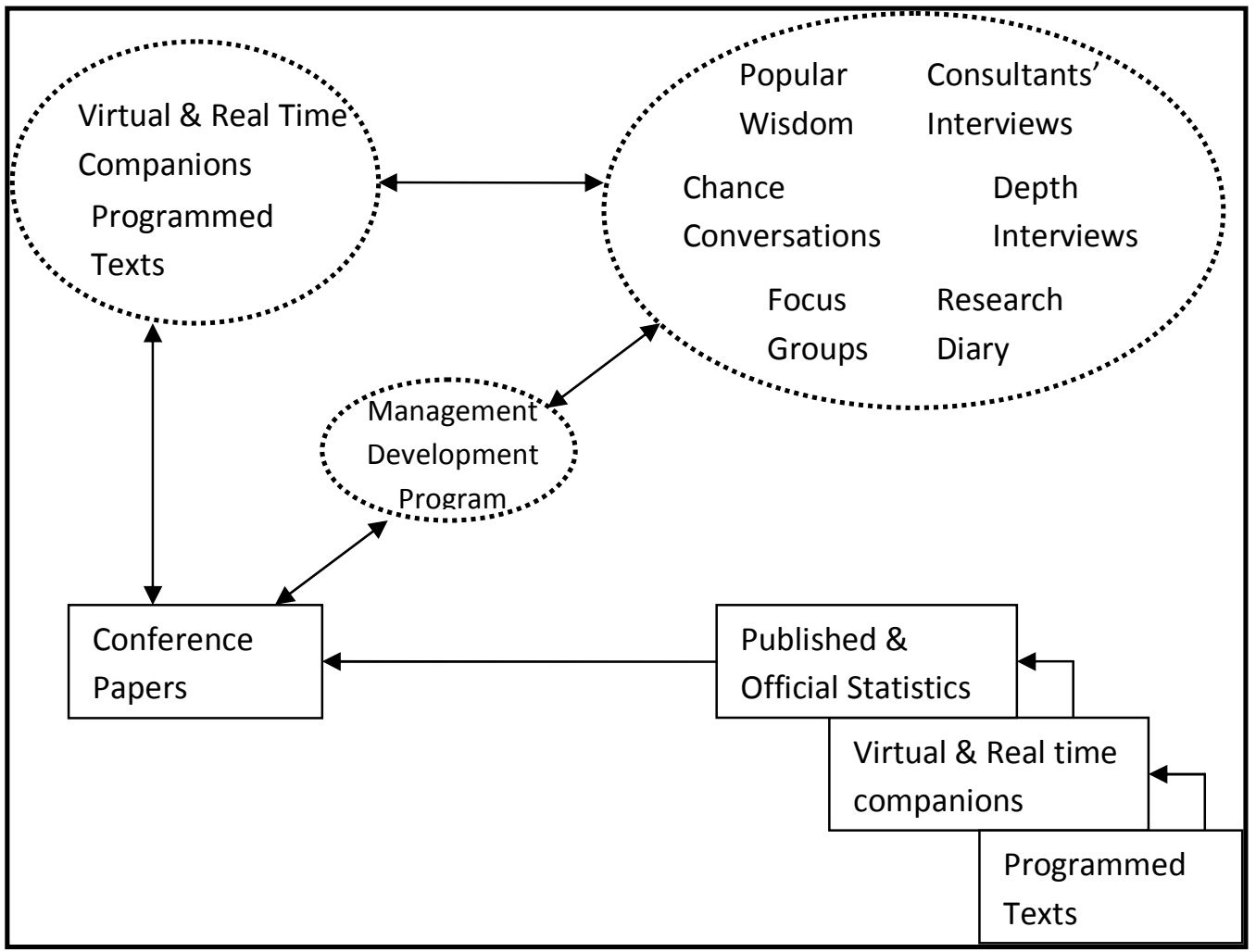

My programmed knowledge consists of influential thinkers who moulded my preunderstanding of how people in general and managers and leaders in particular deal with changing situations: how they engage transformative processes and their daily struggles of problem solving. The common theme is shared emphasis on 'learning' and 'experience' and 'real doing': refer to Knowles' andragogical model (Knowles, 1990; Knowles et al., 2005; 2012), Kolb's action research approach (1984; 1993; 2007), and "earthy activity of doing" (Morris, 1987; 1997). It was in fact Morris' phrase, "just managing” (as in response to being 
asked by a friend, 'How are things then?' and we reply, 'Oh, not so bad. Just managing') that I became intrigued by the non-heroic quality of managers who are simply changing "what is within their existing power to change" becoming something more when activated in what Morris called 'good company': where "In the company of others, we can work to mutual advantage, managing our affairs justly, rather than just managing" (Morris, 1987, p. 115). That was the trigger to my own research voyage. Was finding an answer to the question, ' $X$ ' $s a$ nhawdu?' any different than finding an answer to Morris' question, 'How are things then?' Was there an equivalent in Gozo of Morris' 'just managing' or of 'managing our affairs justly' in how we islanders 'managed' to cope with our day-to-day problems keeping body and soul together?

Another influence on my thinking was Argyris et al.'s (1985) Action Science and their distinction between single-loop and double-loop learning. The former occurs whenever "an error is corrected without questioning or altering the underlying values of the system" (Argyris, 1992, p. 8), the latter, involving reflection to identify assumptions underlying thought patterns, occurring when "mismatches are corrected by first examining and altering the governing variable and then the actions" (Argyris, 1992, p. 9). Double-loop learning supports the "ladder of inference" (Argyris \& Schön, 1974) where underlying assumptions governing our thoughts and behaviour, once identified, can be analyzed and modified to reduce the risk of conclusions insufficiently grounded in data.

With mindsets being targeted, Senge's (2006) idea of the learning organization soon was influencing me too, especially the notion of a collective metanoia or shift of mind for everyone in the organization. Could we attempt to conceptualize a 'collective metanoia' within the Gozitan's business island community, instead of an organizational one? And if we could, what shift of mind would we look forward to? What would our managers and entrepreneurs in Gozo need to do to become Senge's leaders: designers, stewards and teachers of a community that can continually expand its capacity to create its future? Other roleholders - people acting and learning in the company of other people (Pedler, 2012; Pedler et al., 1991; 2013) - came to mind through the notion of who our companions could be: "employees, owners, customers, suppliers, neighbours, the environment and even competitors ..." (Pedler et al., 1991, p. 1).

I realized that, while I could learn a lot from these people, I needed other sources of what could become 'knowledge rich' information, to inspire me on how to inter-relate these theories and mediate these practices effectively. The best way to tap these sources was to engage in a learning experience myself, to reflect upon it and to hopefully draw lessons that would enlighten my practice-research of how people 'manage' to cope with and transcend the complexities between our traditional and modern worlds. To arrive at a better understanding of my situation, I needed to go beyond the prescribed formulations of management development and human resource development theory and practice that for the most part are configured to apply within the realities of large organizations. I needed to inquire insightfully into more basic human processes that managers and entrepreneurs resort to when responding resourcefully and viably to a context characterized by a large and 'bloated' public sector, a couple of firms employing around 100 people, a few small enterprises employing less than 50, and a growing range of partnerships and self-employed entrepreneurs - all conditioned by two main realities: smallness and islandness. 


\section{J. G. Azzopardi}

\section{Exploring insightfully: the islanders' human resourcefulness}

A study on human resource development in small organizations in the UK concluded that,

If we were to generalize these case-study data to a large universe ... it would not be unreasonable to conclude that small organizations quite naturally, and probably unwittingly, develop approaches to human resource development that are located in some guise or other within the vast array of academic and practitioner literature on the subject. Each small organization's model will probably be unique; it will almost certainly be directed as much by internal needs as by external opinion, and it will have been evolved just sufficiently to provide optimum benefit for operational and commercial needs (Hill \& Stewart, 2000, p. 115).

The mission of my research voyage, then, could be to explore the 'unique Gozitan guise' of human resourcefulness. Could I conceptualize how we cope in the 'good company' of one another to secure our internal needs while transforming our destiny? Would there be a 'just sufficient' way that we optimize 'unwittingly' for our own benefits? This sharper focus would entail ceasing to think in terms of 'management development' in order to disconnect from the idea of the organization-based model of people development. The notion of 'human resourcefulness' becomes more connotative to emphasize the informal and natural processes that people continuously and unconsciously deploy in tackling their 'operational and commercial needs'.

At this stage, my inquiry shifted its focus perceptibly. I experienced a shift from an initially exclusive focus upon management development in Gozo towards a focus on how managers and entrepreneurs in Gozo deal with each other in resolving their problems, thus making life viable in their action scene: $x$ 'sa $n \hbar a w d u$ ?

This shift in focus impacted upon the whole process of inquiry. I felt at risk throwing myself into the new (for me) world of grounded theory analysis and beginning to explore insightfully, heavily relying on the willingness of my research participants to collaborate in the research process through in-depth interviews, focus group sessions and chance conversations to generate qualitative data. My own experience of the second phase of the action learning management development program, which never saw the light of day, backed by my pre-knowledge of the 'conspiracy of secrecy' (Baldacchino, 2000) that reigns supreme amongst Gozitan managers and entrepreneurs, increased my anxiety and skepticism that at times culminated in high levels of fear and uncertainty that the whole process would unravel, leaving me empty handed.

Following Silverman's (2013) advice to 'start with what you have', I convinced myself to start analyzing whatever qualitative data I already had at my disposal. I began with the conference papers. In a learning-by-doing spirit, this proved to be a rewarding exercise. It not only opened up the possibility of learning how to rigorously analyze qualitative data, but the process itself started to indicate, in a grounded theory manner, what to start focusing on and where to go next for more data: the process had begun to enable me to start exploring insightfully.

This involved connecting with people presenting in conferences or participating in focus groups and workshops or actively giving of themselves during depth interviews. Their ideas, feelings and assumptions served as the basis for codes to establish patterns and 
conceptualize processes that would guide me forward. Along with these sources of information, I became aware of the potential generation of meaning that could be elicited from idioms, proverbs and everyday common language that discursively constitute and capture the popular wisdom of Gozitans.

I began my analysis by coding the conference papers referred to above. In reading through them, I wrote labels or codes alongside the various sections of the text, be they lines, paragraphs, sections or pages. The codes were either single words or phrases that came to my mind spontaneously as possible indicators - images or projections - of what was being communicated in the text. Or 'in vivo' phrases selected from the islanders' own words that spoke to me as potentially significant to understanding how they deal with their most pressing problems. Concurrently with coding, I was also writing annotations or memos to myself, generating ideas that were prompted by the text that I was coding (or by any other event, be it a chance conversation with a colleague or a friend, a media report, a popular saying or other happenings that occurred and would strike me).

The first few conference papers quickly produced hundreds of codes. On careful examination of these codes, I realized that most of them were not codes at all, but rather repetitions of detailed information and descriptions of facts and ideas that, in and of themselves, were not significant contributions to the analysis. So I had to re-define my focus and to start the coding process again, paying more attention to the 'music' behind the data rather than just the detailed 'scores' of information before me. I became guided by the following self-developed data sampling criteria:

- incidents that keep recurring in the data;

- incidents that inter-relate with other incidents and concepts;

- critically problematic incidents; and

- accounts reflecting highly personal or emotional responses to local phenomena.

The use of these criteria as guidelines to select relevant data facilitated a more sensitive coding process and enabled me to better focus on emergent concepts and their properties. Constantly comparing incidents to incidents and relating them to emerging concepts and properties directed me to recurrent sources of similar appearing information to confirm and/or to elaborate the data, while also regularly returning to the conference papers until I felt that no new ideas were forthcoming.

This developed into an iterative and circular process of sampling data, coding, analyzing the properties of codes, writing memos, and then sorting and re-sorting codes and memos and writing down conceptualized ideas in a somewhat initially haphazard but, for me, meaningful manner. The simultaneous and spiraling cycle of concurrently collecting data, analyzing and writing out their features paralleled an action-reflection process: I was immersing myself in the situation, living the phenomena along with my participants, while regularly retreating to 'crystallize' my findings in the form of transcripts, memos, charts and incomplete write-ups (Borkan, 1999). In retrospect, this process resembles the 'grounded hermeneutic' approach to qualitative research proposed by Addison (1999, p. 147),

I want to emphasize that analysis is not just one step in a linear progression that comes soon after data collection and sometime before writing up the results. Good qualitative research is always more of a circular process than a linear one. Analysis does not fall 


\section{J. G. Azzopardi}

outside this circular or spiral form. Analysis is part of a larger interpretative process. For instance, interpretation begins in the formulation of the problem and the method of investigation. In circular fashion, I return to refine my analytic procedures as I begin to collect data. My developing analysis helps direct my further data collection. The circle of interpretation continues to spiral.

The mechanical aspect of the process involved both computerized devices as well as the traditional use of paper, scissors and wall charts. But, while computer programs can aid and expedite a qualitative research process, they cannot do the generative thinking for the researcher. The use of word-processing software facilitated the writing down of bits and pieces of analytic sections that could continuously be revisited, edited and elaborated with relative ease. This process would have been much more time-consuming if it had been done manually. I therefore made partial use of computer-aided qualitative data analysis software (HyperRESEARCH@ Version 2.0). Although this software is equipped with sophisticated sorting, report generating, code-mapping and even hypothesis-testing features, I limited its use only to expedite and facilitate the coding and memo writing processes and to generate reports. It allowed me to store all the information in one database that could be expanded, retrieved, examined and analyzed promptly and effectively. This facility may remain useful in making the database available for future research by myself, and/or others. For this purpose, and in compliance with the ground rules of anonymity and confidentiality, no names or references to material of a personal nature were included in the transcribed and stored versions of interviews, focus group discussions and chance conversations and dialogues.

Lists of codes and their related bits of texts, transcripts and memos were regularly printed out. These were then examined, cut into smaller pieces when necessary, sorted and resorted and organized into separate piles. As the sorting went on, I looked for themes that would subsume the nature of the emergent content of every pile. I labeled the piles accordingly and wrote the label on wall charts using different colours to visualize probable relationships, connections and links and to distinguish whether the label indicated a condition, process, cause or outcome. This analytic exercise was repeated every time a new range of significant and meaningful ideas came out of the database.

One may well imagine how slow and time consuming the above process felt, especially at the early stages. But, as the research progressed, and I got more familiar with both the contents of my sources and the above devices for analyzing them, the whole process gathered momentum, the more so as the levels of interest, curiosity and excitement escalated. As fragmented bits of analytical writing started to get some shape as text, I could start to sort them into sections and finally into chapters. Then I felt I was reaching the saturation point of no longer needing 'to go out there' to look for more data: for the purposes of this particular research voyage, my sampling and coding of data were sufficient. I was getting closer and closer to my destination. Figure 3 represents one of the flipcharts at a very advanced stage of the research process.

Although links could be observed between the various codes, concepts and properties, a core linking element was still lacking. Something was missing, perhaps a process that would correlate and inter-relate the various themes, processes and ideas with one another, providing a more coherent explanation of the variations that had emerged. Thus, 'fear' and 'suspicion' could clearly be related to 'mistrusting' and so could 'bypassing' and 'distancing' be linked to 'powerlessness'. Other factors could also be inter-related: 'networking', 'lobbying' and 
'corrupting' might belong to the same family; so might 'individualism', 'collectivism' and 'attitude'; as well as 'tacit', 'explicit', 'formality' and 'informality'. But: what process could possibly subsume all the polarities and contradictions into a meaningful whole? Which core category may emerge from the data to provide an answer to $x$ 'sa nћawdu? Just as in the case of the research question, it so happened that the answer was so common and deeply ingrained in our system that it had become invisible: nirrangaw (pronounced nirran-jaw, $\mathrm{j}$ as in jar). In grounded theory terminology, this verb captures the necessary ingredients of fit, relevance, workability and modifiability (Glaser, 1978) that place it at the heart of the process, confirming it as the core category.

\section{Figure 3: Concepts, properties, categories.}

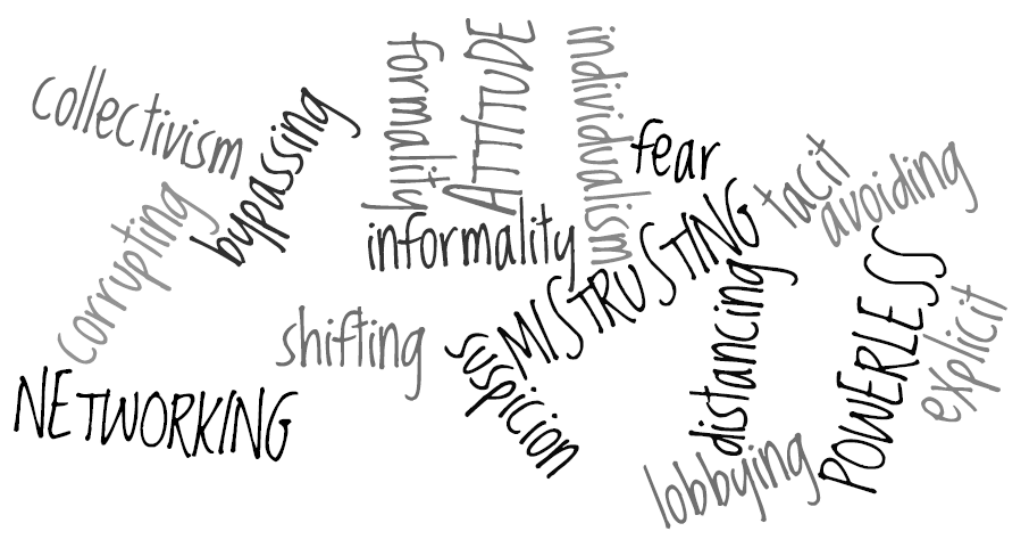

Source: Azzopardi and Mann (2006, p. 43).

Nirrangaw is a verb in the first person plural, derived from the Italian 'arrangiarsi', literally meaning 'we set things right' (Aquilina, 1990, p. 1235). In the infinitive, the verb means,

to put right, to rectify;

to improve oneself, to look better;

to be the cause of trouble to someone;

to settle a difference peaceably, come to an agreement (Aquilina, 1990, p. 1182).

The real meaning of nirrangaw, however, goes beyond these definitions, depending on context. Notwithstanding the constant occurrence in everyday language and in my database, the forceful significance of the word did not occur to me immediately. The verb is such an integral part of our daily struggle to survive, that during the initial stages of my inquiry I overlooked its obvious strong significance, relevance and validity to the inquiry and to the process of how managers continuously 'just manage.' Nirrangaw is the natural answer to the question: X'sa nћawwdu?, or 'How do we manage?'

The process enables managers and entrepreneurs in Gozo to identify the problem and to resolve it, thus making 'life viable in the action scene'. It is the basic socio-psychological process constantly being used by stakeholders, managers and entrepreneurs, to resolve their most pressing problems. 


\section{J. G. Azzopardi}

\section{Discussion}

Two main concepts emerged from analyzing how businesspersons, small business managers and entrepreneurs act and interact with the formal structures in their daily struggle to survive: mistrust and powerlessness (see Figure 4).

First, they mistrust the authorities, formal structures and the people representing them. The predominant attitude is one of fear and suspicion. They are afraid to interact with formal structures and suspect the truth behind initiatives and interventions stemming therefrom.

Second, managers and entrepreneurs in Gozo feel powerless in confrontation with the authorities and the formalities imposed upon them. They therefore seek to distance themselves from the formal structures and look for solutions outside the system, bypassing the established rules and regulations, very often involving themselves in what, externally, would be called corrupt and illicit practices.

Figure 4: Espoused Process.

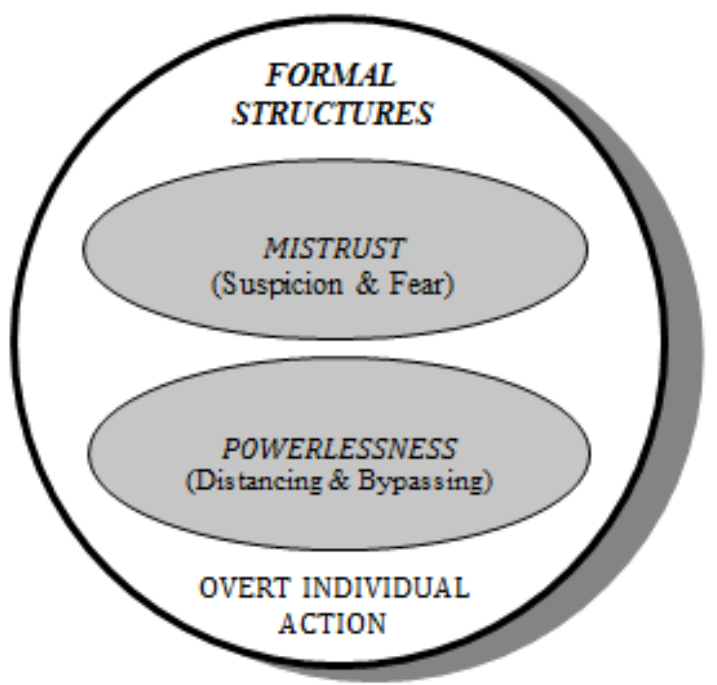

In spite of high levels of mistrust and powerlessness, Gozitan managers and entrepreneurs prefer to manifest proof of individual action: although in an atmosphere of secrecy and silence (Baldacchino, 2000), they covertly solve their problems in the company of others; they overtly pretend to try to solve their problem on their own without the help of others. A situation like this, characterized by mistrust in/of formal structures, powerlessness in confrontation with authorities, and a tendency for all to fend for themselves, contains all the ingredients for social chaos. All three universal social norms that, according to social psychological theory (Moghaddam, 1998) bind Western societies together - trust, truth and respect - seem on the surface and in the fabric to be missing in this community. And yet, people continue to survive; some even to thrive.

This situation prompted a further question: in the apparent absence of the three universal norms, what is it that binds Gozitan island society together and makes life viable? 
Probing for answers to this question raised the core category that links all the other processes together, a basic social psychological process that provides an explanation to an otherwise human situation that lacks the basic norms for survival. Digging deeper, a transformative 'informalizing' process emerged that equips Gozitan managers and entrepreneurs with a pragmatic operational tool to overcome formal barriers imposed upon them by rigid, artificial structures that inhibit communication, performance and achievement. This process acts as the central force, the adhesive that solidly binds the bricks together, constantly in operation, and widely employed across the board at all institutional levels.

\section{Figure 5: 'Theory in use' process}

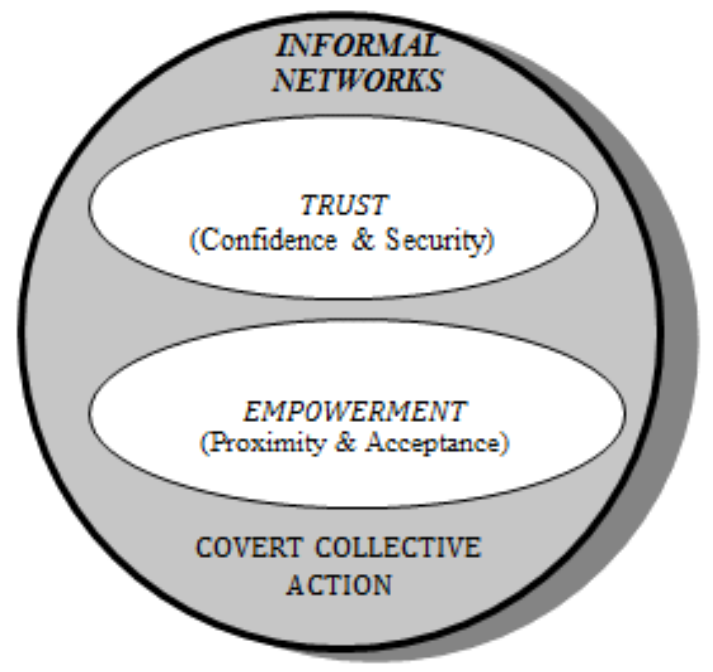

Maintaining the conspiracy of silence and retaining an overt manifestation of individual action, this process enables operators to involve themselves in covert collective action through informal networks, transforming mistrust into trust and powerlessness into empowerment. In the process, the related feelings of fear and suspicion are neutralized and people re-acquire confidence and security, pre-requisites for acting resourcefully.

This process enables the Gozitan islanders to distance themselves from formal structures and to enter into close collegial relationships with friends and/or friends of friends (Figure 5). In this circuit, the rules of the game are well known and readily accepted by every local party, neutralizing consequences of twisting or bypassing formal rules and regulations and transforming what would be interpreted as corruption and illicit practice into acceptable, natural and logical way of doing things - 'just managing' around here. (Figure 6).

"Informalizing" as the basic process that dominates Gozitan islanders' way of doing things, informs, influences and explains the mental model of managers and entrepreneurs in Gozo. The process transforms the attitudes and behaviour indulged into, in response to imposed bureaucratic structures, manifested by feelings of 'mistrust' and 'powerlessness', into 'trust' and 'empowerment'. Protected by the 'culture of secrecy' that dominates the informal and closely-knit networking system, Gozitan managers and entrepreneurs feel 'confident' and 'secure' to recoup 'trust' and to regain 'empowerment'. Through 'proximity' 


\section{J. G. Azzopardi}

to power sources and through the 'acceptance' of the rules of the game, they just manage to solve their most pressing problems in an atmosphere of 'covert collective action'.

This is the Gozo-made mode of 'just managing' in times of change and uncertainty and under conditions characterized by smallness and islandness: the Nirrangaw process. A more detailed account of the development of the process, presenting rich verbal and observational data, has been published elsewhere (Azzopardi \& Mann, 2004).

\section{Figure 6: The NIRRANGAW process: 'just managing'.}

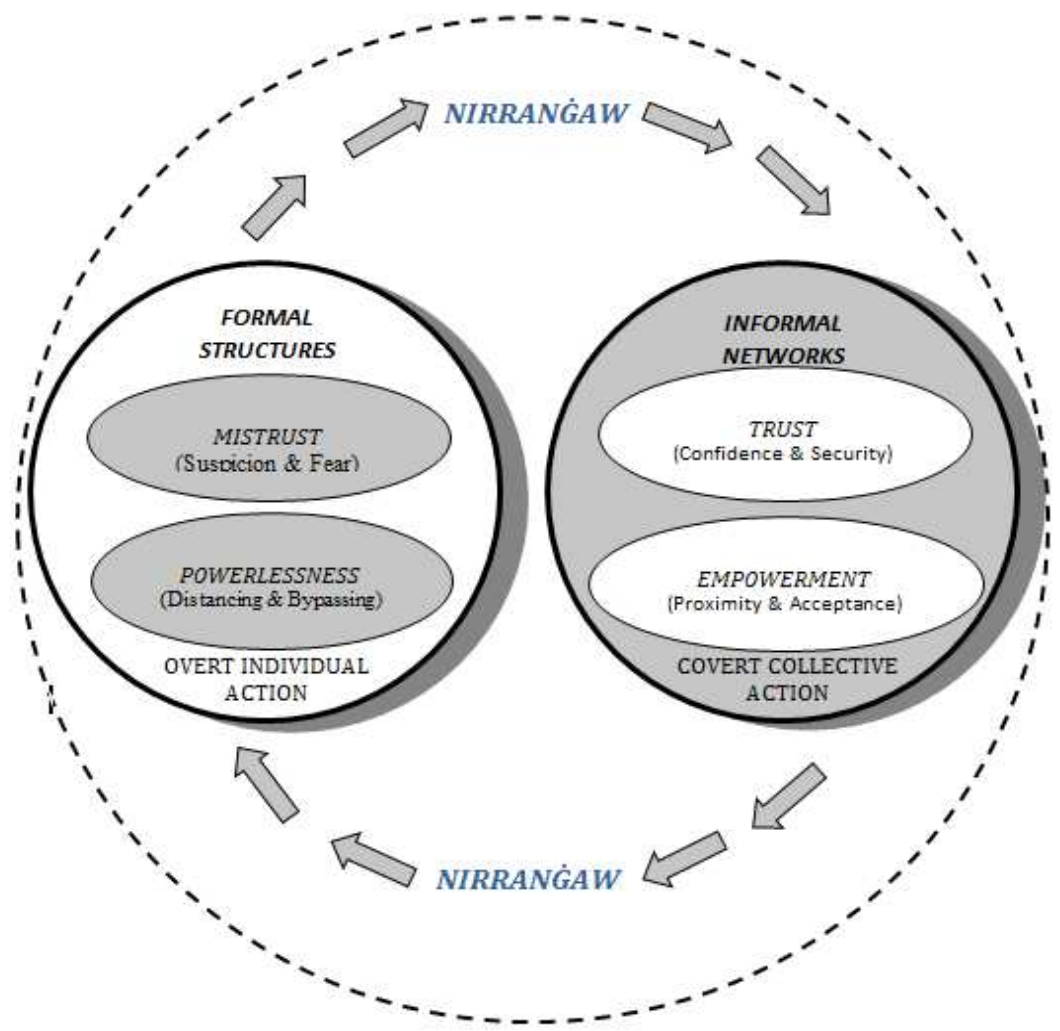

\section{Implications}

Reflecting on the nirrangaw process within the framework of Argyris' and Schön's action science $(1974,1996)$, this locally constructed is a basic social psychological fabric enshrined in the Gozo managers' and entrepreneurs' single-loop mode of learning and development, because it does not address the governing variables that influence their assumptions and beliefs. When activating the nirrangaw process, their 'action strategy' produces the expected 'results/consequences' of solving the immediate crisis, yet keeping them trapped within a 'functioning system' that has always worked to help them 'just manage' to solve their most pressing problems.

Even though businesspersons, managers and entrepreneurs might become aware during the problem solving process that there is some mismatch between their espoused theory (the formal side of the nirrangaw process) and their theory-in-use (the informal side), they tend to transform the mismatch into a fit between their intention and the outcome of their 
action to satisfy their beliefs and values which they are keen to maintain. They seem to be reluctant to reflect on the mismatch of their espoused theory with their theory-in-use and to do something to change the variables that govern their behaviour by challenging the fundamental assumptions and beliefs that influence their frame of mind. Figure 7 illustrates this by depicting the nirrangaw process superimposed on the single-loop learning mode, excluding the other processes that might direct these islanders towards double-loop learning and development processes.

\section{Figure 7: Nirrangaw: a single loop development process?}

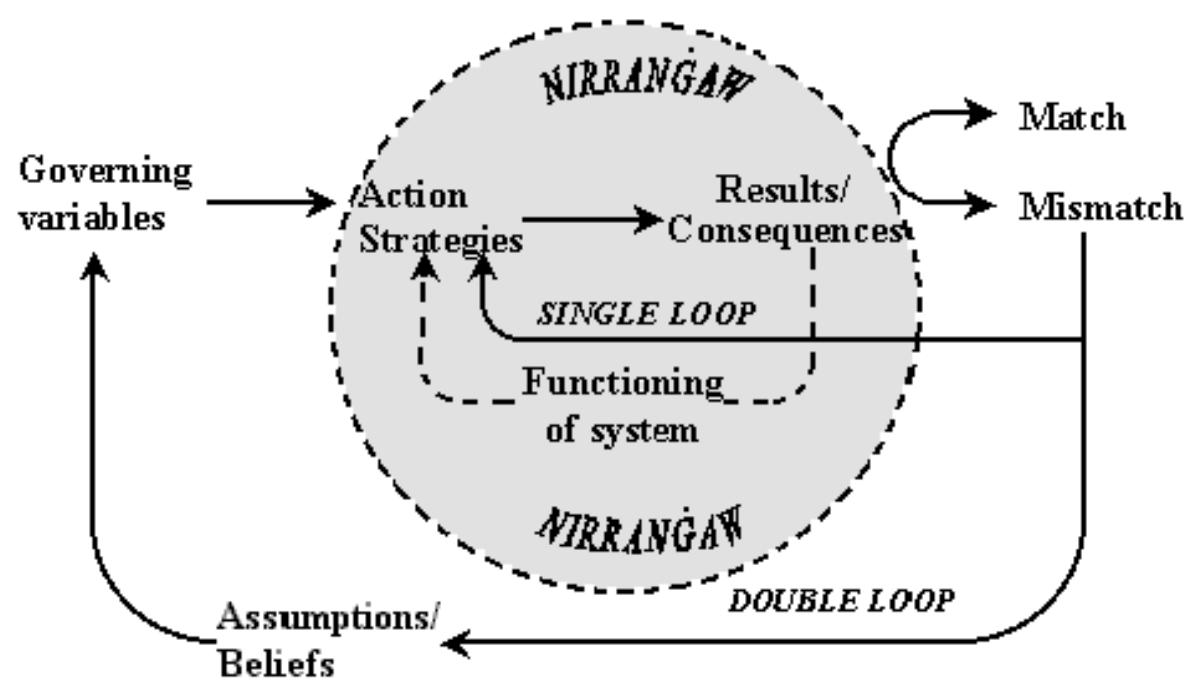

Adapted from Argyris et al. (1985).

Starting by reflecting on the 'formal side' of the coin of the basic social psychological process, one can understand that 'mistrust' and 'powerlessness' are the governing values or variables of which Gozitans are very much aware: they do not trust the formal structures and they feel helpless when confronted with problems of power that have to do with government bureaucratic procedures or with any other form of institutional authority. They have therefore learned how to overcome mistrust and powerlessness by naturally reverting to the other side of the coin: activating the nirrangaw process, they turn to their informal network of friends, relatives or friends of friends, gatekeepers to power, and so resolve their pressing concerns. Having solved their problems, they return to their daily routines without seeking to question the basic assumptions that have just influenced their action strategy or whether it would be feasible to seek out alternative ways of acting.

As much as they are aware of the formal side of the coin, the informal side however happens naturally and unwarily: "We are rarely aware of this type of theory of action because it is ingrained in us from early childhood" (Argyris, 1991, p. 86). The grounded approach to this inquiry, like the 'ladder of inference' (Argyris \& Schön, 1996), has helped me become aware of, conceptualize, and codify this tacit process that may well be the outcome of past experiences dominated by an atmosphere of islanders growing up in a tight network of interrelationships: a surveillance society. 


\section{J. G. Azzopardi}

The main consequence that can be associated with being locked inside the single-loop routine is the overprotection of the status quo; this might hinder Gozitans from devising innovative problem-solving and creative ways forward. What can be done to get islanders out of the "self-sealing" (Argyris, 1991, p. 87) process that they have learned to activate since early childhood and in which they have become highly skilled? Can the nirrangaw process serve as a springboard to take these islanders out of this self-sealing loop so that they can start to change themselves and what goes on around them?

Senge (2006) helps to explain this behaviour. In the context of smallness and islandness, aggravated by over-reliance on the bigger sister island for survival and the lack of innovative business opportunities, businesspersons in Gozo can and do not afford to risk and to make mistakes. They, therefore, prefer to defend their turf, protecting themselves from possible outside threats. If they start by focusing their attention on their own mental models and thereby develop an awareness of what is influencing their habits to see their problems as existing 'out there,' they may be taking the first step to start realizing how they contribute to their own problems and what they can do to resolve them.

They can then move on to address the issue that self-reliant development models and strategies cannot be imported, but have to be locally and organically constructed through a process of empowerment. This study suggests that Gozitan businesspersons and entrepreneurs are highly skilled in how to 'just manage'. Just managing may have served their requirements so far, but there are indications that they might be reaching the critical juncture: if they do not move on to locally develop complementary skills of resourcefulness that would serve them the purpose of shaping their own destiny - rather than overly relying on 'others' to do it for them - they will find it ever harder to make ends meet. So, from 'just managing,' what can they do to learn how to start to 'manage justly'? This potential conceptual shift in their frame of mind was inspired by Morris, who condensed the idea of the "Good Company" in one sentence: "In the company of others, we can work to mutual advantage, managing our affairs justly, rather than just managing" (Morris, 1987, p. 115).

'Managing justly' means achieving a firmer mastery over both internal self and external world. This includes a commitment to be 'honest' with oneself in admitting one's ignorance as a pre-condition for one's own internal change that is mandatory in an action learning manner. Becoming conscious of the tacit processes used to solve problems and to deal with uncertain and changing situations, such as the nirrangaw process, will hopefully lead to a better understanding of the self and of the external world, leading to a firmer grip over both. Perhaps, one actionable step forward to start 'managing justly' the development of human resourcefulness in Gozo is the admittance that "without the power to discard beliefs shown to be wrong ... one cannot introduce action known to be right" (Revans, 1998, p. 86).

\section{Conclusion}

This study addresses a real island phenomenon in real time: an exploratory voyage into how the islanders of Gozo resolve their most pressing problems in order to survive, called for a nissological approach. Studying islands and islanders on their own terms enabled the researcher to immerse himself into the real world of islanders resulting in explicating a basic socio-psychological process that elucidates how businesspersons, entrepreneurs and small business managers activate their human resourcefulness to survive and some even to thrive under conditions of smallness and islandness. 
Adopting a nissological approach to research inductively the islanders' human resourcefulness enabled an in-depth inquiry into the processes and tactics they activate to make life viable and to mitigate the perceived challenges and disadvantages of their real life situation. Studying the island on its own terms involved the re-exploration and the reformulation of the research question itself. Letting the question emerge from the voices of the islanders enabled the active search for the real answer to that question: nirrangaw is the natural action in response to $x$ 'sa nћawdu?

There at least two implications from this study. First, these results came to light because the researcher departed from conventional research methods driven by deductive analytics and ventured into inductive processes that seek to dig deeper into real life situations. Second, the lessons learnt imply that islanders develop their own unique way of operating successfully, because, or in spite, of daunting challenges they have to face in order to survive. This is why this paper has outlined, in some detail, the research process itself, in order to entice other researchers into considering the application of nissological, inductive research processes to explore other pertinent and critical issues and concerns faced by islanders.

\section{References}

Addison, R.B. (1999). A grounded hermeneutic editing approach. In B.F. Crabtree \& W. Miller (Eds.), Doing qualitative research ( $2^{\text {nd }}$ edn.) (pp.145-162). London: Sage.

Aquilina, J. (1987). Maltese-English dictionary $(A-L)$. Malta: Midsea Books.

Argyris, C., Putnam, R. \& Smith, D. (1985). Action science. San Francisco CA: Jossey-Bass.

Argyris, C. (1992). On organizational learning. Oxford: Blackwell.

Argyris, C. \& Schön, D.A. (1974). Theory in practice: Increasing professional effectiveness. San Francisco CA: Jossey-Bass.

Argyris, C., \& Schön, D.A. (1996). Organizational learning. Vol. 2: Theory, method, and practice. New York; Addison-Wesley.

Azzopardi, J., \& Mann, P. (2006). Nirrangaw: a basic social psychological process in an island community. In C. Arcidiacono \& H. Legewie (Eds.), Learning communities and sustainable socio-economic development (pp. 34-53). Retrieved from: http://psydok.sulb.uni-saarland.de/volltexte/2006/756

Baldacchino, G. (2000). The social structure: issues and implications. In BOV (Eds.), 2000 Gozo conference: Improving the employability of the Gozo workforce (pp.15-28) Malta: BOV.

Bank of Valletta (Eds) (2000). 2000 Gozo Conference: Improving the Employability of the Gozo Workforce. Malta: BOV.

Borkan, J. (1999) Immersion/crystallization. In B.F. Crabtree \& W. Miller (Eds.), Doing qualitative research ( $2^{\text {nd }}$ edn.) (pp. 179-194). London: Sage.

Briguglio, L. (Ed.) (2000). The effects of European Union membership on the island region of Gozo. Malta: Formatek.

Crabtree, B.F. \& Miller, W.L. (eds.) (1999). Doing qualitative research. London: Sage.

Gill, J., \& Johnson, P. (2010). Research methods for managers. London: Sage.

Glaser, B.G. (1978). Theoretical sensitivity: Advances in the methodology of grounded theory. Mill Valley, CA: Sociology Press.

Glaser, B.G. (1992). Emergence vs forcing: Basics of grounded theory analysis. CA: Sociology Press. 


\section{J. G. Azzopardi}

Glaser, B.G. (2008). Conceptualization: On theory and theorizing using grounded theory. International Journal of Qualitative Methods, 1(2), 23-38.

Gummesson, E. (2000). Qualitative methods in management research. London: Sage.

Gummesson, E. (2006). Qualitative research in management: addressing complexity, context and persona. Management Decision, 44(2), 167-179.

Hill, R., \& Stewart, J. (2000). Human Resource Development in Small Organizations, Journal of European Industrial Training, 24/2/3/4, 105-117.

Knowles, M.S. (1990). The adult learner: A neglected species. Houston TX: Gulf Publishing.

Knowles, M.S., Holton, E.F., \& Swanson, R. (2005). The adult learner: A definitive classic in adult education and human resource development. London: Elsevier.

Knowles, M.S., Holton, E.F., \& Swanson, R. (2012). The adult learner. London: Routledge.

Kolb, D.A. (1984). Experiential learning: Experience as the source of learning and development. Englewood Cliffs, NJ: Prentice-Hall.

Kolb, D. A. (1993). The process of experiential learning. In M. Thorpe, R. Edward \& H. Hanson (Eds.), Culture and process of adult learning. (pp. 138-156). New York: Open University Press.

Kolb, D.A., Osland, J.S., Rubin, I.M., \& Turner, M.E. (2007). Organisational behaviour: An experiential approach $\left(8^{\text {th }}\right.$ edn.). New Jersey: Pearson Education.

McCall, G. (1994). Nissology: the study of islands, Journal of the Pacific Society, 17/2-3, 1-4.

McCall, G. (1997). Nissology: a debate and discourse from below. Presented at Cultural Heritage in Islands and Small States Conference, Valletta, Malta, May 8-10.

McCall, G. (2002). Nissology: something to think about and something to protect-beyond the boundaries. Proceedings of IUCN/WCPA-EA-4 Taipei Conference (pp. 18-23). March.

Moghaddam, F.M. (1998). Social psychology: Exploring universals across cultures. New York: W.H. Freeman.

Morris, J. (1974). Joint development activities. Management Review and Digest 1(1), 3-5.

Morris, J. (1987). Good company. Management Education \& Development, 18(2), 103-115.

Morris, J. (1994). Development work and the learning spiral. In A. Mumford (Ed.), Gower handbook of management development (pp.127-138). Aldershot: Gower.

Morris, J. (1997). Minding our Ps and Qs. Action learning in practice, 3(1), 49-60.

National Statistics Office (2012). Gozo in Figures 2007-2012, Valletta, Malta: NSO.

Pedler, M., Burgoyne, J., \& Boydell, T. (1991). The learning company: A strategy for sustainable development. London: McGraw-Hill.

Pedler, M. (2012). Action learning for managers. London: Gower Publishing.

Pedler, M., Burgoyne, J., \& Boydell, T. (2013). A manager's guide to self-development. New York: McGraw-Hill International.

Remenyi, D., Williams, B., Money, A., \& Swartz, E. (2005). Doing research in business and management: An introduction to process and method. London: Sage.

Revans, R.W. (1998). ABC of action learning: Empowering managers to act and to learn from action. London: Lemos and Crane.

Revans, R. (2011). ABC of action learning. London: Gower.

Sayer, A. (1992). Method in social science: A realist approach ( $2^{\text {nd }}$ edn.) London: Routledge.

Senge, P.M. (2006). The fifth discipline (revised edition). New York: Broadway Business.

Silverman, D. (2013). Doing qualitative research: A practical handbook. London: Sage.

Smith, M. J. (1998). Social science in question. London: Sage and Open University.

Stringer, E.T. (2014). Action research ( $4^{\text {th }}$ edn.). London: Sage. 